\title{
CULTURA E FEDERALISMO NA TRAJETÓRIA CONSTITUCIONAL BRASILEIRA
}

\section{CULTURE AND FEDERALISM IN TRAJECTORY BRAZILIAN CONSTITUTIONAL}

\section{CULTURA Y FEDERALISMO EN LA TRAYECTORIA CONSTITUCIONAL BRASILEÑA}

\begin{abstract}
SIDNEY SOARES FILHO
Doutor e Mestre em Direito Constitucional pela Universidade de Fortaleza (Unifor). Professor da graduação e pósgraduação da Universidade de Fortaleza (Unifor). Fortaleza, Ceará, Brasil. http://lattes.cnpq.br/9218335907593806 / http://orcid.org/0000-0003-4107-6290 / sid_filho@hotmail.com
\end{abstract}

\begin{abstract}
MARCELO DiAs PONTE
Doutorando em Direito Constitucional pela Universidade de Fortaleza (Unifor). Advogado. Professor da Universidade de Fortaleza (Unifor. Fortaleza, Ceará, Brasil. http://lattes.cnpq.br/0828676892229232 / http://orcid.org/0000-0003-0372-3039 / marceloponte@unifor.br
\end{abstract}

\begin{abstract}
RESUMO
O Brasil é uma das federações mais antigas do mundo, sendo instituída em 1891 em nosso Estado. A forma federativa brasileira influencia, até hoje, usos e costumes formadores da nossa cultura e que merecem e devem ser preservados pela legislação. Este trabalho analisa a cultura e a proteção de todo seu patrimônio pode ser extremamente beneficiada com a estrutura federativa do estado em especial no caso brasileiro, onde a legislação constitucional vigente assegura, inclusive, ações de forma cooperada entre os três níveis de poder, (União, estados-membros e municípios) para que tais entes atuem de modo conjunto propiciando o que for de melhor para o Estado. Fez-se uso de uma metodologia baseada em pesquisa bibliográfica, artigos, sítios digitais, jornais e entrevistas com profissionais que vivenciaram todo esse processo de mudança, além do uso de gráficos e tabelas.
\end{abstract}

Palavras-chave: Federalismo. Cultura. Histórico das Constituições Brasileiras

\begin{abstract}
Brazil is one of the oldest federations of the world, being instituted in 1891 in our State. The Brazilian federative form influences, until today, customs and customs that form our culture and that deserve and must be preserved by the legislation. This work analyzes the culture and the protection of all its patrimony can be extremely benefited by the federative structure of the state, in particular in the Brazilian case, where the constitutional legislation in force assures, even, actions in a cooperative way between the three levels of power, , Member states and municipalities) so that these entities act together to provide what is best for the State. We used a methodology based on bibliographic research, articles, digital sites, newspapers and interviews with professionals who experienced this whole process of change, besides the use of charts and tables.
\end{abstract}

Keywords: Federalism. Culture. History of the Brazilian Constitutions.

\section{RESUMEN}

Brasil es una de las federaciones más antiguas del mundo, siendo instituida en 1891 en nuestro Estado. La forma federativa brasileña influye, hasta hoy, usos y costumbres formadoras de nuestra cultura y que merecen y deben ser preservados por la legislación. Este trabajo analiza la cultura y la protección de todo su patrimonio puede ser extremadamente beneficiada con la estructura federativa del estado en especial en el caso brasileño, donde la legislación constitucional vigente asegura, incluso, acciones de forma cooperada entre los tres niveles de poder, (Unión , Estados miembros y municipios) para que tales entes actúen de modo conjunto propiciando lo que sea de mejor para el Estado. Se hizo uso de una metodología basada en investigaciones bibliográficas, artículos, sitios 
digitales, periódicos y entrevistas con profesionales que vivenciaron todo ese proceso de cambio, además del uso de gráficos y tablas.

Palabras clave: Federalismo. Cultura. Historia de las Constituciones Brasileñas.

\section{SUMÁRIO}

INTRODUÇAO; 1 A CULTURA NA CONSTITUIÇÃO DE 1824 E AS PERSPECTIVAS DE FEDERALISMO NO IMPÉRIO BRASILEIRO; 2 FEDERALISMO E CULTURA NA CONSTITUIÇÃO DE 1891; 3 FEDERALISMO E CULTURA NA CONSTITUIÇÃO DE 1934; 4 FEDERALISMO E CULTURA NA CONSTITUIÇÃO DE 1937; 5 FEDERALISMO E CULTURA NA CONSTITUIÇÃO DE 1946; 6 FEDERALISMO E CULTURA NA CONSTITUIÇÃO DE 1967; 7 FEDERALISMO E CULTURA NA CONSTITUIÇÃO DE 1988; CONCLUSÃO; REFERÊNCIAS.

\section{INTRODUÇÃO}

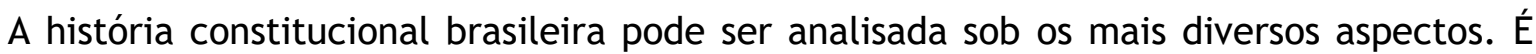
comum fazermos esse estudo tomando-se como base alguns acontecimentos marcantes na conjuntura de um país para que a compreensão seja avaliada dentro de um determinado contexto, ou ainda excluída quando determinado período não se enquadra nos tópicos a serem explorados em um determinado trabalho.

Desse modo, ao fazermos o estudo sobre o federalismo e a cultura no constitucionalismo brasileiro, deixaremos de lado todo o período colonial até nossa independência, em virtude de não possuíamos legislação constitucional própria naquela época.

Entretanto, não olvidaremos em esboçar alguns momentos de nossa história colonial que são importantes o suficiente para que se compreenda o início e as razões do constitucionalismo no Brasil principalmente sob o aspecto cultural, uma vez que significativa parte de nossas tradições, usos, costumes em todos são frutos de um legado histórico oriundo de nosso passado que envolveu o colonizador europeu, os escravos vindos do continente africano e os silvícolas que habitavam o território sul americano no período de nossa descoberta.

A miscigenação surgida dessas três raças acarretou também uma miscigenação cultural que hoje ainda se refletem das mais diversas formas, seja na culinária, seja no hábito de dormir numa rede ou mesmo nas manifestações folclóricas e musicais.

O Brasil como uma das federações mais antigas do mundo instituída em 1891 traz até hoje esses usos e costumes formadores da nossa cultura e que merecem e devem ser preservados pela legislação. O federalismo, por sua vez é uma forma de organização estatal onde há uma desconcentração do poder do estado em outros níveis com a distribuição de competência entre 
os mesmos. Dentro dessa perspectiva, pretende-se com o federalismo com essas demais competências, a atuação setorizada em níveis mais setorizados no território estatal criando assim um binômio basilar do sistema federativo: a unidade e a diversidade.

A unidade federativa permite a coesão das esferas de poder desconcentrado onde cada uma atua de modo a atender aos anseios e necessidades daquela porção territorial de modo coordenado e organizado em prol da federação como um todo. A diversidade é decorrente do respeito ás esferas desse poder onde cada porção territorial possui características peculiares que necessitam de ações diferenciadas umas em relação ás outras para que a federação assim possa prosperar.

Desse modo, a conquista e do ponto de interseção ideal entre a unidade e diversidade dentro de uma federação seja talvez um dos seus principais desafios, mesmo sabendo das restrições e limitações constitucionais impõem a cada federação.

No tocante á cultura e proteção do patrimônio cultural, acreditamos que o federalismo brasileiro diante do binômio entre unidade e diversidade se alia á questão cultural, no momento em que de acordo com nossa Carta Política, o Estado deve garantir a todos o pleno exercício dos direitos culturais ao mesmo tempo em que protege as manifestações culturais oriunda das raças e povos que formam o povo brasileiro específica em diversas regiões do nosso território.

Pretende-se demonstrar assim, que, inobstante as mais diversas oscilações que o federalismo brasileiro sofreu durante sua trajetória constitucional, seja com características dualista, regionalista, e, recentemente com previsão cooperada, resgatando o hiato que tivemos em períodos marcados por uma forte centralização, a questão relativo à cultura e a proteção do patrimônio cultural veio acompanhando tais momentos, sendo atual momento o que merece maior destaque no que se refere à valorização da cultura e proteção do patrimônio cultural, não somente pelos dispositivos próprios relativos à matéria bem como pela previsão normativa de atuação conjunta entre os entes da federação, cooperação esta ainda carecedora de normatização específica.

\section{A CULTURA NA CONSTITUIÇÃO DE 1824 E AS PERSPECTIVAS DE FEDERALISMO NO IMPÉRIO BRASILEIRO}

Logo após a sua conquistar sua independência, uma das primeiras medidas tomadas pelo então Império Brasileiro foi de possuir sua legislação própria, principalmente no que diz respeito 
á elaboração primeira constituição. A assembleia constituinte de 1823 onde de esboçava um projeto de constituição para nosso país foi dissolvida pelo imperador, tendo o este outorgado nossa primeira carta constitucional em 1824.

Antes, porém, adianta-se uma peculiaridade da gênese do Federalismo brasileiro, o qual, segundo Bonavides “[...] já nasceu enfermo e cresceu raquítico, eivado de contradições e impurezas centralizadoras que the desfiguram a imagem; um federalismo açoitado de ameaças autocráticas e unitárias, geradoras de injustiças e ressentimentos."

A primeira constituição brasileira caracterizou-se por sua plasticidade, ou seja, a sua adequação nas condições econômicas, políticas e sociais da época, que fizeram com que a mesma tivesse longo período de vigência, praticamente sem sofrer emendas. 0 momento histórico de um Estado que acabara de surgir e buscava se autoafirmar como nação independente fizeram com que as o regime monárquico e a concentração do poder visando com que nosso país mantivesse a unidade e integridade territorial fossem considerados os objetivos mais almejados naquele momento.

Sob o aspecto histórico devemos reconhecer que a Carta de 1824 atendeu ás pretensões da época onde o nosso país conseguira se firmar com dimensões continentais sob o regime monárquico, em pleno continente americano cujos países vizinhos adotavam uma forma republicana, fruto de uma fragmentação territorial. A palavra federação soava, como sinônimo de separatismo. 0 regime federativo que culminou na formação dos Estados Unidos da América ainda seria ousado demais para nossa conjuntura. No que diz respeito a questão cultural, aquela constituição era praticamente omissa, apenas dispondo que colégios e universidades ensinarão elementos de ciências, belas artes e letras.

Acreditamos, porém que mesmo que houvesse uma maior preocupação com qualquer temática que envolvesse a questão cultural em termos normativos, estes careceriam de efetividade, uma vez que boa parte do nosso território não era povoada, seus habitantes não tinham instrução além dos indígenas e dos negros serem considerados mais como "coisa" do que realmente como “pessoa”. Sobre o assunto, observe-se as palavras de Darcy Ribeiro, dispõe da seguinte forma:

A instituição social que possibilitou a formação do povo brasileiro (...) velho uso indígena de incorporar estranhos à sua comunidade. Consistia em lhes dar uma moça índia como esposa. Assim que ele a assumisse, estabelecia

\footnotetext{
${ }^{1}$ BONAVIDES, Paulo. A Constituição Aberta. Temas políticos e constitucionais da atualidade, com ênfase no Federalismo de Regiões. $2^{a}$ Ed. São Paulo: Malheiros, 1996, p. 442.
} 
automaticamente, mil laços que o aparentavam com todos os membros do grupo. ${ }^{2}$

A maior densidade populacional concentrava-se já no sudeste brasileiro, tanto em quantidade quanto em instrução. Os estudos demonstram que a vinda da família real portuguesa para o Brasil em 1808 já representou um aumento populacional bem como no nível intelectual, de modo significativo.

Naturalmente, a vinda do rei de Portugal em 1808 para o Rio de Janeiro foi um marco importante, pois com ele veio também a Corte, com cerca de 16 mil pessoas de formação educacional bem superior a que se encontrava no Brasil. Isso representou um acréscimo de cerca de $7 \%$ da população nessa província. Esse acréscimo, somente em uma cidade, gerou grande desequilíbrio de capital humano entre as regiões ${ }^{3}$.

Desse modo, o acesso ás manifestações culturais á época, teatro, música e as artes em geral eram extremamente limitadas à elite intelectual da época. Os rituais indígenas, suas línguas, seus costumes, a adoração aos seus deuses era desprezada, assim como todos os rituais e hábitos dos descendentes africanos, castrados em sua liberdade de crença e culto religiosos, na música e outras tradições.

No reinado de D. Pedro I, pouco há o que se falar em relação á questão cultural. Já no Reinado de seu filho, D. Pedro II, muito foi feito para propagação das artes e da cultura. De acordo com Oliveira Lima, “O próprio imperador era por demais intelectual, e era o que bastava para ele favorecer essa brilhante eclosão do espírito. As letras, com efeito, encontraram sempre nele um ardente protetor e simpático a todas as suas fórmulas" ${ }^{4}$.

Dentre os mais diversos méritos rendidos ao nosso imperador, destacamos a Criação do Instituto Histórico e Geográfico Brasileiro (IHGB), quando nosso monarca, ainda com pouca idade despontaria como um estadista de significativa e reconhecida dotação intelectual. Sobre o citado instituto, Schwarcz dissera:

A partir dos anos 50 o IHGB se afirmaria como um centro de estudos bastante ativo, favorecendo a pesquisa literária, estimulando a vida intelectual e funcionando como um elo entre esta e os meios oficiais. Assim, com seus vinte anos, a suposta marionete se revelaria, aos poucos, um estadista cada vez mais

\footnotetext{
${ }^{2}$ RIBEIRO, Darcy. O Povo Brasileiro: A formação e o sentido de Brasil. 2a ed. São Paulo: Companhia das Letras, 1995, p. 72.

${ }^{3}$ BARROS, Alexandre Rands. Desigualdades Regionais e Desenvolvimento Econômico. In Pedro Ferreira... et al. Desenvolvimento Econômico: uma perspectiva brasileira. Rio de Janeiro: Elsevier, 2013, p.443.

${ }^{4}$ LIMA, Oliveira. Formação da Nacionalidade Brasileira. 3ed. Rio de Janeiro: Publifolha, 2000, p. 212.
} 
popular e sobretudo uma espécie de mecenas das artes, em virtude a ambição de dar autonomia cultural ao país. ${ }^{5}$

E, ao contrário do que muitos pensam, a participação do Imperador d. Pedro II não se restringiu apenas á colaboração financeira para manutenção do citado instituto, o que, se apenas esta ocorresse, já era digna de mérito. Nosso imperador foi extremamente atuante, tendo o mesmo participado até mesmo as vésperas da proclamação da república, como afirmou a citada autora, na página seguinte ao dizer:

Se desde o início o Estado entrava com $75 \%$ das verbas da Instituição, a partir de 1840, d. Pedro II passará a frequentar com assiduidade as reuniões na sede localizada no Paço imperial. Dessa data em diante, o Instituto Histórico funcionará como uma espécie de porto seguro, um estabelecimento oficial para as experiências do jovem monarca, crescentemente empenhado em imprimir "um nítido caráter brasileiro" á nossa cultura. A participação do imperador não era, portanto, a partir dos anos 50, apenas financeira. Ao contrário, d. Pedro interessou-se pessoalmente pelo IHGB, tendo presidido um total de 506 sessões de dezembro de 1849 até 7 de novembro de 1889 - só se ausentando em caso de viagem. ${ }^{6}$

Infelizmente, apesar do esforço estatal para criação de um instituto desse vulto, com a participação ativa do nosso então chefe de Estado nunca foi lembrada ou, é na verdade, totalmente desconhecida pela quase totalidade da população brasileira. Por outro lado, toda forma de manifestação cultural e de fomento á cultura era praticamente restrito á sede do império, no Rio de Janeiro e nas sedes de algumas poucas províncias do nosso território que, de tão vasto e de difícil acessibilidade e administração, se tornava praticamente impossível a disseminação e difusão do ensino das belas artes e das letras em âmbito nacional como assegurava a Constituição de 1824. Por outro lado, por mais que houvesse uma maior atenção por parte de nosso Imperador pela questão da cultura, esta era adstrita á aristocracia local, coincidente com elite política da época.

Nos quatro cantos do país, as manifestações culturais existiam, mas sem reconhecimento. Imigrantes que vinham residir no Brasil, além das culturas indígena e negra já citadas eram existentes, porém desprezadas mas que hoje refletem na formação da nossa identidade cultural. O Brasil era, por sua natureza, multicultural. Aliado a isso, nossa geopolítica tornava nosso país diferente em várias partes de seu território, fruto não só da

\footnotetext{
${ }^{5}$ SCHWARCZ, Lília Moritz. As barbas do imperador: D. Pedro II, um monarca dos trópicos. 2ed. São Paulo; Companhia das Letras, 2003, p. 126.

${ }^{6}$ SCHWARCZ, Lília Moritz. As barbas do imperador: D. Pedro II, um monarca dos trópicos. 2ed. São Paulo; Companhia das Letras, 2003, p. 127.
} 
dimensão territorial mas da centralização política da época que acarretava cada vez mais nas disparidades sociais e regionais até hoje existentes. 0 movimento republicano associado ao regime federativo começou a tomar força nas últimas décadas do império.

Aliás, diga-se que a existência de conflitos interéticos sempre existiu, mesmo sem a colonização européia, uma vez que as tribos indígenas lutavam entre si. Porém, este conflito foi acentuado após a chegada dos portugueses e demais povos no território brasileiro. Sobre o assunto, Darcy Ribeiro assim dispõe:

Conflitos interéticos existiram desse sempre, opondo as tribos indígenas umas às outras. Mas isso se dava sem maiores consequências, porque nenhuma delas tinha possibilidade de impor sua hegemonia às demais. A situação muda completamente quando entra nesse conflito um novo tipo de contendor, de caráter irreconciliável, que é o dominador europeu e os novos grupos humanos que ele vai aglutinando, avassalando e configuram com outra macroetnia expansionista. $^{7}$

O jurista alagoano Aureliano Cândido de Tavares Bastos, em uma de suas mais conhecidas obras, A província: estudos sobre a descentralização do Brasil, já demonstrara certa preocupação do mesmo com a questão da centralização política e administrativa brasileira onde o autor menciona diversos aspectos pelos quais o Brasil era merecedor de tornar-se uma federação.

Em uma das análises, o autor reconheceu a existências de diferentes grupos existentes da vastidão territorial brasileira e que a centralização não era capaz de proteger tal diversidade, mas somente através da adoção do sistema federativo de governo exatamente para proteger e tratar da reconhecida diversidade social e cultural brasileira no século XIX, como na citação a seguir:

Abstrahi do presente um instante, volvei alguns annos na fantasia; figurai-vos a perspectiva geral do Brasil no próximo século; será temerário suppôr do Amazonas, cujas feições se estão pronunciando ao sol do equador, que o do $\mathrm{S}$. Francisco, linha de união, ligando o sul ao extremo norte, que a região tropical banhada pelo Parahyba e limitada pelas montanhas do rio, minas e S.Paulo, que 0 rio-Grande e Santa Catharina que se germanisam a olhos vistos, que o vastíssimo oeste estendido das margens do Tocantins ás do Paraguay, bem depressa ostentem cada um, não diremos tendências contrarias e repugnantes mas traços distinctos, civilisações desiguaes, como são distinctas e desiguaes suas raças predominantes. $^{8}$

\footnotetext{
${ }^{7}$ RIBEIRO, Darcy. O Povo Brasileiro: A formação e o sentido de Brasil. 2a ed. São Paulo: Companhia das Letras, 1995, p. 153.

${ }^{8}$ BASTOS, Aureliano Cândido de Tavares. A Província - Estudo sobre a descentralização no Brasil. Brasília: Edição Fac-Similar. Senado Federal, 1996, p. 23.
} 
Assim como Tavares Bastos, diversos outros intelectuais da época manifestavam-se a favor do federalismo, como Assis Brasil e Rui Barbosa, este último com a manutenção do regime monárquico. A manifestação republicana ganhou força nacional através dos jornais e folhetins que eram publicados na época.

O império não conseguia mais conter as aspirações da população. E esse período foi significativo para a difusão da imprensa jornalística como agente difusor da propagação literária, principalmente no cenário político. Como dissera Oliveira Lima,

O Império foi, não obstante, por sua atmosfera de liberdade, a idade de ouro do jornalismo brasileiro. Desde José Justiniano da Rocha até Quintino Bocaiúva, o estilo excedeu a paixão, e o país conheceu uma série de mestres do gênero. As letras em geral tinham-se desenvolvido muito e aliás de maneira constante através das lutas políticas. ${ }^{9}$

Observa-se assim, que o componente a conjuntura política do movimento republicano e federalista proporcionou o exercício de liberdade de expressão principalmente pelos adeptos á causa republicana e ao federalismo, promovendo o desenvolvimento de estilos literários dos mais diversos pelos escritores da época. Assim, findou-se o império e nasce a república, carregando consigo o tão almejado sistema federativo.

\section{FEDERALISMO E CULTURA NA CONSTITUIÇÃO DE 1891}

A Constituição de 1891, a primeira da nossa república e que veio acoplada ao regime federativo já introduziu alguns dispositivos relativos á cultura ou atividades correlatas no que diz respeito á propriedade intelectual e a proteção do patrimônio, como veremos mais adiante. Primeiramente, o legislador á época, ao regulamentar as algumas atribuições do Congresso, mas fazendo a ressalva no artigo 35 que esta atribuição não era privativa. Dentre os seus parágrafos, encontramos o segundo que assim disciplinava: “Animar, no país, o desenvolvimento das letras, artes e ciências, bem como a imigração, a agricultura, a indústria e o comércio, sem privilégios que tolham a ação dos governos locais". ${ }^{10}$

Observamos com a leitura do parágrafo em referência que o incentivo constitucional á produção artística e literária não foi pontual, tem o mesmo tratado do assunto de modo

\footnotetext{
9 LIMA, Oliveira. Formação da Nacionalidade Brasileira. 3ed. Rio de Janeiro: Publifolha, 2000, p. 211.

10 BRASIL. Constituição Federal. Brasília: Senado Federal, 1891. Disponível em: https://www.planalto.gov.br/ccivil_03/constituicao/constituicao24.htm. Acesso em: 23 dez. 2016.
} 
bastante generalizado inserindo tais temas a outros bastantes diversos como agricultura, indústria e comércio.

Na seção destinada a Declaração de Direitos, o único dispositivo que mencionava algo que de certo modo tangenciasse a proteção cultural no que se refere a direitos autorais era o artigo 72, § 26, que estabelecia o seguinte: “Aos autores de obras literárias e artísticas é garantido o direito exclusivo de reproduzi-las pela imprensa ou por qualquer outro processo mecânico. Os herdeiros dos autores gozarão desse direito pelo tempo que a lei determinar".

Assim, estava assegurado constitucionalmente o direito a reprodução das obras artísticas e literárias, sendo concedido aos seus criadores não só a exclusividade no direito de reproduzi-las, mas a transmissão desses direitos para os herdeiros em caso de sucessão hereditária. Dessa proteção legal, podemos extrair também que o Estado, mesmo que de forma não intencional autorizava a produção literária uma vez que concedia os direitos de reprodução dos escritos.

Por fim, a derradeira menção que o legislador do final do século XIX fez no tocante á questão da cultura, encontra-se quase oculta no texto daquela Carta Política, por ter sido inserida nas disposições transitórias. 0 artigo se refere á proteção patrimonial e preservação da memória histórica do nosso país que, por ser bastante específica, não encontramos nenhuma outra sequer parecida ou equivalente nas demais constituições republicanas. Trata-se da aquisição, pelo governo Federal da casa de Benjamin Constant, conforme se verifica no artigo abaixo citado:

Art $8^{\circ}$ o Governo Federal adquirirá para a Nação a casa em que faleceu o Dr. Benjamin Constant Botelho de Magalhães e nela mandará colocar uma lápide em homenagem á memória do grande patriota - o fundador da República.

Parágrafo único. A viúva do mesmo Dr. Benjamin Constant terá, enquanto viver, o usufruto da casa mencionada. ${ }^{11}$

Como salientamos, em nenhuma constituição do país o legislador tenha tratado da preservação da memória de modo tão peculiar. Localizada no bairro de Santa Teresa, na cidade do Rio de Janeiro, o Museu Casa de Benajmin Constant situa-se numa área de preservação ambiental - APA de 10.500 metros quadrados e abriga documentos, fotografia, livros e objetos daquele que foi engenheiro, professor, militar e homem público, tendo recebido a alcunha de "fundador da república".

11 BRASIL. Constituição Federal. Brasília: Senado Federal, 1891. Disponível em: https://www.planalto.gov.br/ccivil_03/constituicao/constituicao24.htm. Acesso em: 23 dez. 2016. 
Ressalte-se ainda que Benjamin Constant foi diretor por muitos anos do Imperial Instituto dos Meninos Cegos, instituição criada por D. Pedro II em 1854. Com a proclamação da República, o prédio recebeu a denominação de Instituto Benjamin Constant e que trata até hoje de pessoas portadoras de deficiência visual, sendo um dos prédios históricos mais imponentes do Rio de Janeiro.

Contudo, a previsão normativa de aquisição da casa que fora construída para servir de residência para o Sr. Antônio Moreira Costa dos Santos em 1860, havia sido alugada por Benjamin Constant em 1889. Dois anos depois, com seu falecimento, sua esposa Maria Joaquina ficou como usufrutuária, assim como sua filha Aracy. O tombamento do imóvel pelo IPHAN (Instituto do Patrimônio Histórico e Artístico Nacional) ocorreu em 1958 após parecer de Carlos Drumond de Andrade, mas somente adquiriu a condição de museu tendo sido aberto ao público no ano de 1982.

Analisando esse breve histórico podemos observar que, inicialmente a pretensão do legislador era tão somente adquirir o imóvel para a "Nação", ou seja, torná-lo um bem público. Felizmente, os sucessivos governos permitiram que a simples aquisição de uma casa, com a afixação de uma lápide, culminasse na preservação até os dias atuais de um imóvel que se tornou museu aberto á visitação pública, privilegiado ainda com o fato da referia moradia estar circundada a uma área de proteção ambiental.

Da análise dos dispositivos relativos á cultura e proteção do patrimônio intelectual e material, bem como da memória histórica, observem que todos eles estavam situados de modo disperso em partes diferentes de nossa Constituição. Acreditamos que a conjuntura á época não permitiu que o legislador constituinte tratasse e protegesse a questão cultural quando o próprio destino do estado estava em jogo.

A mudança de um regime monárquico para um republicano, diga-se de passagem, sem que houvesse revoltas de largas proporções em sua transição, a mudança do estado unitário para que fosse adotado o sistema federativo, alteraria consideravelmente a estrutura do estado brasileiro. Toda a unidade e integridade territorial conquistada e mantida no império haveria de ser preservada.

A manutenção da unidade e integridade territoriais eram, na época os principais objetivos do império, necessitando de uma forte atuação à época do imperador para que não ocorresse no Brasil o que aconteceu com a América espanhola. 0 governo enérgico para manter 
um país extenso era uma necessidade já inclusive descrita pelos autores federalistas, pois, caso contrário não seria possível manter tal união. ${ }^{12}$

A abolição da escravatura, fato este que também foi significativo para mudanças na economia e estrutura social do país um ano antes da proclamação também foi um acontecimento de extrema relevância na história política e social do país, mas que foi esquecido pelos legisladores á época.

Essa omissão de não adotar qualquer política pública no evento que, de uma hora pra outra acarretou enormemente nas disparidades sociais do país, trouxe-nos prejuízos das mais diversas ordens e que infelizmente pagamos um elevado preço pelas atuais disparidades sociais, regionais, sem falar em questões ligadas ao preconceito, sistemas de cotas que, somente agora passados mais de um século, o legislador constituinte resolveu voltar atenção.

Em sua mais recente obra "Pensadores que Inventaram o Brasil", ao comentar sobre Joaquim Nabuco, e a questão da abolição da escravatura, Fernando Henrique Cardoso assim se manifestou:

Refiro-me á conclusão de que a Abolição, ao não ter vindo acompanhada de medidas que indicassem a responsabilidade social dos brancos pela situação degradada dos negros, não trouxe consigo a democratização da ordem social. Desprovidos dos recursos mínimos para o exercício da cidadania, os negros passaram de cativos a excluídos, sem oportunidades reais de uma inserção positiva no processo produtivo. ${ }^{13}$

Dando continuidade ao trecho citado, constatamos que o estado foi omisso em questões mais fundamentais como o respeito mínimo á dignidade da pessoa humana. Nenhum procedimento de inserir os "ex escravos" no mercado de trabalho, fizeram com que muitos deles, mesmo após de alcançada a libertação, retornassem ás fazendas onde moravam pedindo comida e moradia em troca de seu serviço braçal.

Nos primeiros anos de nossa república organizada sob a forma federativa, onde os estados membros passariam a ser regidos por sua própria constituição, desde que respeitados os princípios constitucionais da União. É o que prescrevia o artigo 63 da Constituição de 1891. Também, a mesma constituição dispunha que cada estado deveria prover ás suas expensas as necessidades de seu governo e administração. Assim, se as desigualdades sociais eclodiram com

\footnotetext{
12 MADISON, James; HAMILTON, Alexander; JAY, John. Os Artigos Federalistas. Apresentação: Isaac Kramnick; tradução de Maria Luiza X. de A. Borges. Rio de Janeiro: Nova Fronteira, 1993, p. 146.

${ }_{13}$ CARDOSO, Fernando Henrique. Pensadores que inventaram o Brasil. São Paulo: Companhia das Letras, 2013, p.19.
} 
a abolição da escravatura, essa determinação constitucional de auto-sustento para os estados membros fizeram crescer ainda mais as disparidades regionais existentes.

Essa inabilidade governamental já era prevista por Montesquieu, quando assim se manifestou: "Se uma república é pequena, ela é destruída por uma força estrangeira; se é grande, destrói-se por um vício interno"14.

Apesar da época em que escrevera sua obra "Do Espírito das Leis", o nobre pensador francês parecia tratar desde aquela época da questão da governabilidade. E, nosso passado histórico permite assegurar que Montesquieu estava certo ao fazer tal afirmação. O Brasil já era deficitário de governabilidade desde o sistema de capitanias hereditárias á época de sua colonização donde apenas duas prosperaram.

Após a independência já comentamos que as dificuldades de se conhecer melhor toda nossa extensão territorial de conhecer de perto os problemas locais. 0 preço pago pela atual dimensão continental brasileira foi exatamente decorrente das disparidades sociais e regionais que perduram até hoje, sendo uma das principais mazelas de nossa atualidade.

O federalismo em sua essência é calcado em dois pilares básicos; a unidade e a diversidade. Encontrar o ponto de equilíbrio em cada uma das nações que adotam essa forma de organização estatal é que é o grande desafio.

Infelizmente, o receio de fragmentação territorial nos moldes como ocorrera no restante da América espanhola perdurou durante nosso império e adentrou na república. Além disso, os 67 anos de regime monárquico centralizador foi herdado pelo nosso presidencialismo de modo que não havia qualquer interesse estatal em desconcentrar o poder para os estados recémcriados. Ao contrário do que aconteceu nos Estados Unidos da América, nosso federalismo ocorreu por desagregação e não por agregação de estados.

O desenvolvimento nacional foiçou ainda mais limitado nos primeiros anos de nossa federação em decorrência da República café com leite, cujo poder era alternado por governantes dos estados de São Paulo e Minas Gerais. Esse fato político de extrema relevância para nossa história causou reflexo direto no sistema federativo, uma vez que esse conchavo entre os dois estados demonstrava de maneira clara os interesses das elites políticas locais, deixando em segundo plano o desenvolvimento da nação como um todo.

\footnotetext{
${ }^{14}$ MONTESQUIEU ( Charles Louis de Secondat). Do Espírito das Leis. Rio de Janeiro: Nova Cultural, 1997, p. 173.
} 
Assim, a citada unidade, como um dos pilares do federalismo inexistia, comprometendo a diversidade no sentido mais amplo que se possa imaginar de nossa vasta dimensão territorial. Diversidade de clima, culturas, hábitos que geram problemas de natureza local que eram desconhecidos ou desprezados pelos governantes.

O descaso, como já mencionado, gerou disparidades regionais o que consequentemente reflete nos aspectos econômicos que merecem ser combatidos. Sobre o assunto, Furtado se pronunciou:

No Brasil, a luta pelo federalismo está ligada ás aspirações de desenvolvimento das distintas áreas do imenso território que o forma. Não se coloca entre nós o problema de choque de nacionalidades, de agressões culturais ligadas a disparidades étnicas ou religiosas. Mas sim o da dependência econômica de certas regiões com respeito a outras, de dissimetria nas relações entre regiões de transferências unilaterais de recursos encobertas em políticas de preços administrados. Na diversidade das regiões estão as raízes de nossa riqueza cultural. Mas a preservação dessa riqueza exige que o desenvolvimento material se difunda por todo o território nacional. ${ }^{15}$

Assim, na visão de Celso Furtado, o desenvolvimento regional seria condição fundamental para o crescimento econômico, onde em várias regiões se percebe a diversidade cultural brasileira que merece ser preservada.

\section{FEDERALISMO E CULTURA NA CONSTITUIÇÃO DE 1934}

No anteprojeto da Constituição de 1934, elaborada pela comissão nomeada pelo Chefe do Governo Provisório, através do Decreto 21.402 de 14/05/1932 art.34 dispunha que a iniciativa das leis pertence: “e) ás associações culturais e ás profissionais devidamente reconhecidas". Importante salientar que o anteprojeto destinava um título próprio (TíTULO XI) destinado á Cultura e ao Ensino. Cabe aqui destacar o artigo 111 que assim estava descrito:

Art.111. São livres a arte, a ciência, e o seu ensino.

$\$ 1^{\circ}$ Incumbe á União, aos Estados e aos Municípios dar-lhes proteção e favorecerlhes o desenvolvimento.

$\$ 2^{\circ}$ Gozam de amparo e solicitude dos poderes públicos os monumentos artísticos, bem como os históricos e os naturais.

$\$ 3^{\circ}$ Cabe á União impedir a emigração do patrimônio artístico nacional. ${ }^{16}$

\footnotetext{
${ }^{15}$ FURTADO, Celso. Essencial Celso Furtado. São Paulo, Penguin Classics Companhia das Letras; 2013, p. 378.

16 BRASIL. Constituição Federal. Brasília: Senado Federal, 1934. Disponível em:
} 
Infelizmente o poder conferido ás associações culturais existentes á época e devidamente reconhecidas pelo governo federal para propor projeto de lei não passaram do anteprojeto, uma vez que estas não tiveram, na promulgação do texto oficial tal legitimidade.

Entretanto, a Constituição de 1934, inspirada na Constituição de Weimar (1919), trouxe inúmeras inovações para o Estado brasileiro, principalmente no que se refere aos direitos sociais. Mas aqui, concretiza-se pela primeira vez o federalismo cooperativo, ou seja, a permissão constitucional de práticas de ações cooperadas entre os entes autônomos da federação que, á época, restringia-se á união e aos Estados Membros, insculpidos no artigo $9^{\circ}$ que assim determinava:

Art. $9^{\circ}$ é facultado á União e aos Estados celebrar acordos para a melhor coordenação e desenvolvimento dos respectivos serviços e, especialmente, para a uniformização das leis, regras ou práticas, arrecadação de impostos, prevenção e repressão de criminalidade e permita de informações. ${ }^{17}$

Por conseguinte, o artigo 10 do citado diploma legal, disciplinava em seus incisos, as ações que podiam ser implementadas concorrentemente entre os dois entes da federação. Dentre os tópicos agraciados, detectamos o inciso terceiro, o qual faz alusão á proteção do patrimônio histórico, artístico e natural, conforme podemos observar na redação abaixo:

Art. 10. Compete concorrentemente á União e aos Estados:

I - velar na guarda da Constituição e das leis;

II - cuidar da saúde e assistências públicas;

III - proteger as belezas naturais e os monumentos de valor histórico ou artístico, podendo impedir a evasão de obras de arte;

IV- promover a colonização;

V - fiscalizar a aplicação das leis sociais;

$\mathrm{VI}$ - difundir a instrução pública em todos os seus graus;

VII - criar outros impostos, além dos que lhes são atribuídos privativamente. ${ }^{18}$

Interessante registrar que naquela época o legislador constituinte reservara um capítulo específico no texto constitucional titulado "DA EDUCAÇÃO E DA CULTURA” dando certo relevo á questão cultural em seu artigo 148 que assim estabelecia:

https://www.planalto.gov.br/ccivil_03/constituicao/constituicao34.htm. Acesso em: 23 dez. 2016.

17 BRASIL. Constituição Federal. Brasília: Senado Federal, 1934. Disponível em: https://www.planalto.gov.br/ccivil_03/constituicao/constituicao34.htm. Acesso em: 23 dez. 2016.

18 BRASIL. Constituição Federal. Brasília: Senado Federal, 1934. Disponível em: https://www.planalto.gov.br/ccivil_03/constituicao/constituicao34.htm. Acesso em: 23 dez. 2016. 
Art. 148. Cabe á União, aos estados e aos Municípios favorecer e animar o desenvolvimento das ciências, das artes, das letras e da cultura em geral, proteger os objetos de interesse histórico e o patrimônio artístico do País, bem como prestar assistência ao trabalhador intelectual. ${ }^{19}$

Entretanto, é forçoso reconhecer que por melhores que sejam das intenções dos constituintes o que se busca é a efetivação dos direitos insculpidos na norma. Por outro lado, a constituição anterior, fora praticamente omissa em regulamentar a questão cultural.

Acreditamos que as manifestações sociais e culturais posteriores a primeira guerra mundial tenham sido de vital importância para uma nova ordem constitucional de uma realidade diversa de despontava no horizonte. Tratando especificamente sobre a questão cultural, destacamos a Semana de Arte Moderna ocorrida em são Paulo, no ano de 1922.

Uma semana que na verdade durou cinco dias, de efeito inversamente proporcional á sua repercussão e importância no campo cultural e político. O rompimento com a academia, ou seja, com as técnicas tradicionais de simetria, dava lugar ás figuras disformes e assimétricas tão bem ilustrada na tela que mais representa o movimento titulada Abaporu, de Tarsila do Amaral que, ironicamente, encontrava-se em Paris durante o evento assim como a citada obra que fora concluída de 1928.

Entretanto Tarsila, assim como Anita Malfatti podem ser consideradas como duas das principais personalidades do movimento conhecido como Modernismo que posteriormente teve sua segunda fase, conhecida como antropofágica. A representação do trabalho em pinturas e gravuras, a liberdade de criação se manifestara na poesia, na música e nas demais apresentações demonstrava o desejo de mudança, de quebra de paradigmas, de ruptura de tradições.

O movimento modernista se coadunava com o a realidade política da época. A conhecida República Velha, com a aristocracia paulista tradicional, a alternância de poder entre São Paulo e Minas Gerais que ficou conhecida como República Café com Leite, estava por sofrer mudanças, assim como ocorrera no campo cultural. 0 federalismo dual estadunidense dava lugar ao federalismo cooperativo inspirado na constituição alemã de Weimar. Seguindo essas tendências, foi que o federalismo brasileiro também sofrera mudanças adotando-se também o federalismo cooperativo, com previsão de ações cooperadas na esfera cultural.

19 BRASIL. Constituição Federal. Brasília: Senado Federal, 1934. Disponível em: https://www.planalto.gov.br/ccivil_03/constituicao/constituicao34.htm. Acesso em: 23 dez. 2016. 
Infelizmente, a linha tênue entre a cooperação entre os entes federados e a intervenção fez com que aquele cedesse lugar a esta última, impedindo que nosso sistema federativo cujos anseios de renovação foram tão discutidos durante a constituinte, não lograsse o êxito almejado.

\section{FEDERALISMO E CULTURA NA CONSTITUIÇÃO DE 1937}

O momento político da década de 1930, conhecido como "Estado Novo", apesar de configurar como um momento de extrema centralização político-administrativa com Getúlio Vargas no poder, foi, na mesma época, um período de desenvolvimento da indústria cultural. Enquanto no texto constitucional de 1937 , o legislador extirpou até mesmo a palavra federação ao limitar-se em dizer que “ 0 Brasil é uma república” logo em seu artigo primeiro ${ }^{20}$.

Nesse mesmo período foi o momento que em surgem legislações específicas para a proteção do patrimônio cultural, com destaque para o anteprojeto de criação do SPAN - serviço do Patrimônio Artístico Nacional e a criação do Conselho Nacional de Cultura - CNC. Nesse período, o rádio eclodira como meio de comunicação, pessoas que de tornaram posteriormente grandes personalidades na cultura do país, como Mário Lago e Cauby Peixoto. Não somente o rádio, mas o cinema também ganhou popularidade, num período ditatorial.

A Constituição de 1937, alcunhada de "Polaca" por ter sido inspirada nos moldes da constituição polonesa teve menos de dez anos de vigência. Naquele período o mundo estava sob tensão, por conta da segunda grande guerra mundial que duraria alguns anos. A criação do Conselho Nacional de Cultura em 1938 com diversas atribuições, mas sem poder de deliberação, com viés meramente consultivo que, dependendo de sua atuação poder-se-ia ou não pensar na criação de um “Departamento" Nacional de Cultura, como dissera o então ministro Gustavo Capanema ao Presidente Getúlio Vargas.

$\mathrm{Na}$ mesmo ano era criado o DASP - Departamento Administrativo do Serviço Público, cuja função era controlar a máquina administrativa brasileira. A respeito do sistema político do Estado novo, Bercovici assim se manifestou:

O novo sistema político doo Estado Novo conjugava as interventorias e sua assessoria, realizada por órgãos burocráticos subordinados ao DASP (Departamento Administrativo do Serviço Público), ambos sujeitos ao Presidente. A centralização também se manifestava com órgãos técnico-administrativos que

20 BRASIL. Constituição Federal. Brasília: Senado Federal, 1937. Disponível em: https://www.planalto.gov.br/ccivil_03/constituicao/constituicao37.htm. Acesso em: 23 dez. 2016. 

inúmeros institutos e autarquias criados nessa época. ${ }^{21}$

Assim, os organismos de proteção á cultura criados, eram controlados pelo estado e, alguns de seus membros nomeados pelo próprio Presidente á época. De igual modo, algumas das manifestações culturais como o teatro e o cinema tinham competência legislativa da União, como prescrevia o artigo 16, XVIII.

E aqui fazemos uma consideração importante. A cultura num país, seja num período de abertura democrática, seja num período de centralização política sempre eclodirá de alguma forma. Numa democracia, onde a liberdade de criação e de pensamento são perenes, as manifestações culturais se apresentam sob uma diversidade impressionante em todos os seus segmentos.

Num período antidemocrático, a cultura floresce também, como manifestação ás vezes contrária a conjuntura, avessa ás tradições do lugar, exatamente como forma de manifestação do pensamento que, embora camuflada, acaba existindo e, somente depois tem reconhecido o seu valor cultural.

$\mathrm{Na}$ constituição de 1937, os dispositivos referentes á cultura vinham associados ao da educação. 0 artigo 128 foi pródigo em considerar dever de o Estado contribuir direta e indiretamente para o seu estímulo, como se percebe na transcrição do citado dispositivo: "Art. 128. A arte, a ciência e o seu ensino são livres à iniciativa individual e à de associações ou pessoas coletivas, públicas e particulares"22.

É dever de o Estado contribuir, direta e indiretamente, para o estímulo e desenvolvimento de umas e de outro, favorecendo ou fundando instituições artísticas, científicas e de ensino.

Além desse dispositivo, vale destacar o artigo 134 , em que o legislador conferiu especial proteção estatal aos monumentos históricos, artísticos e naturais, transcrito da seguinte forma: “Art. 134. Os monumentos históricos, artísticos e naturais, assim como as paisagens ou os locais particularmente dotados pela natureza, gozam da proteção e dos cuidados especiais da

\footnotetext{
${ }^{21}$ BERCOVICI, Gilberto. Dilemas do Estado Federal Brasileiro. Porto Alegre: Livraria do Advogado, 2004, p. 41 .

BRASIL. Constituição Federal. Brasília: Senado Federal, 1937. Disponível em: https://www.planalto.gov.br/ccivil_03/constituicao/constituicao37.htm. Acesso em: 23 dez. 2016.
} 
Nação, dos estados e dos municípios. Os atentados contra eles cometidos serão equiparados aos cometidos contra o patrimônio nacional"23.

Observa-se assim, que o governo estabeleceu certa coação para qualquer ato praticado contra os citados monumentos equiparando-os em caso de atentado, (o que se pode traduzir por destruição, depredação, poluição) com as mesmas sanções relativas a delitos contra o patrimônio nacional.

De qualquer forma, mesmo diante de uma norma protetora de patrimônio cultural conjugada com sanções, fruto do regime autoritário, tiveram seu lado positivo pelo receio de descumprimento da mesma por parte de alguns e de penas severas, fazendo com que o patrimônio histórico e natural fosse mais respeitado pela população do que nos dias de hoje.

Ainda a respeito da temática, observemos também que o legislador tratou de proteger o patrimônio em referência pelas três esferas da administração, ou seja, a União, os estados e os municípios, o que, implicitamente se traduziria como uma competência concorrente, numa conjuntura em que nem de fato nem de direito podíamos dizer que éramos uma federação.

Portanto, na transição das décadas de 1930 e 1940, num dos momentos de nossa história política onde a democracia minguava, contraditoriamente, o setor cultural florescia. Mas vale destacar que isso não significa dizer cultura e democracia andam na mesma via em sentidos opostos. O que ocorre, na verdade é que a cultura no Brasil enquanto caminha numa reta sempre em ascensão no que se refere á proteção dos direitos, criação de organismos e entidades de preservação cultural e artística, a democracia brasileira, assim como o federalismo se projetam em nossa história como uma senoides em nossa trajetória constitucional, oscilando com certa frequência, tendo alcançado uma constância ascendente a partir da constituição de 1988.

\section{FEDERALISMO E CULTURA NA CONSTITUIÇÃO DE 1946}

A redemocratização brasileira com o fim da "Era Vargas" e o advento da Constituição de 1946 fez com que vivenciássemos uma maior descentralização no país em comparação a Constituição de 1937. Nesse período, o legislador deu ênfase á questão regional e

23 BRASIL. Constituição Federal. Brasília: Senado Federal, 1937. Disponível em: https://www.planalto.gov.br/ccivil_03/constituicao/constituicao37.htm. Acesso em: 23 dez. 2016. 
desenvolvimentista. Houve uma preocupação em tratar das disparidades sociais e regionais existentes. Como assevera Bercovici:

Foi sob a vigência dessa Constituição, da década de 1950, que a Questão Regional ganhou importância no debate político nacional, com a concepção de que a atuação estatal e o planejamento eram elementos essenciais para o desenvolvimento, de acordo com as diretrizes elaboradas pela recém-criada CEPAL (Comissão Econômica para América Latina). Desde então, todas as constituições brasileiras têm a preocupação de tentar consagrar instrumentos para a superação das desigualdades regionais. ${ }^{24}$

Desse modo, um das metas governamentais durante a vigência dessa constituição era, sem dúvida, tentar resolver o problema dessas desigualdades oriundas não somente de um passado histórico de descaso do poder público em relação as regiões brasileiras, deixando algumas delas á margem do contexto nacional, assim como em decorrência de fatores físicos, dentre eles as secas na região nordeste do país.

Para resolver os problemas de cada região, foram criadas as superintendências. Dentre elas, merece destaque a SUDAM (Superintendência para o Desenvolvimento da Amazônia) e a SUDENE (Superintendência para o Desenvolvimento do Nordeste).

Apesar de atribuírem ineditismo ao Brasil no tocante a esses órgãos governamentais para resolver problemas específicos de cada região, a sua criação na verdade foi inspirada nas “Cassas per il Mezzogiorno" existente s na Itália que já tratavam de combater as disparidades ocorridas naquele país entre a porção sul e a porção norte do território, visando maior equilíbrio.

Infelizmente, esses organismos não conseguiram implementar de maneira plena as suas pretensões. Muitos desses organismos criados funcionaram como "cabide de emprego" para que políticos colocassem familiares e amigos para exercerem os cargos, esquecendo-se assim do compromisso precípuo. A Sudene, por exemplo, criada por Celso Furtado em 1959 chegou a ser extinta muitos anos depois, tendo sido recriada no governo do Presidente Lula, mas que não apresentou até hoje sinais de eficiência e desempenho das atividades a qual se propunha.

No aspecto da cultural, três dispositivos constitucionais merecem destaque. 0 primeiro, o Art.173 que determina que "As ciências as letras e as artes são livres”. Outro, mais específico,

\footnotetext{
${ }^{24}$ BERCOVICI, Gilberto. Dilemas do Estado Federal Brasileiro. Porto Alegre: Livraria do Advogado, 2004, p.42.
} 
Art. 174 “O amparo á cultura é dever do Estado"25. Por fim, o art. 175 que dispõe que: “As obras, monumentos e documentos de valor histórico e artístico, bem como os monumentos naturais, as paisagens e os locais dotados de particular beleza ficam sob a proteção do poder público"26.

Nada de inovador ocorreu na seara cultural que merecesse destaque. Porém a construção da nova Capital Federal no governo Juscelino Kubitschek provocou um maior povoamento para o interior do país, uma vez que a sede do Distrito Federal se localizaria no Planalto Central.

Interessante destacar que, apesar de estarmos na vigência da constituição de 1946, a construção da Brasília já era prevista desde o início da República, como se vê com a redação do artigo $3^{\circ}$, caput, da Constituição de 1891: “Art. $3^{\circ}$ fica pertencendo á União, no planalto central da República, uma zona de 14.400 quilômetros quadrados, que será oportunamente demarcada, para nela estabelecer-se a futura Capital Federal"27.

A cidade de Brasília foi reconhecida em 1987 pela UNESCO como patrimônio cultural da humanidade. Esse título foi o primeiro para um bem com características contemporâneas a merecer tal distinção pela perspectiva de futuro, de modelo de cidade projetada por Oscar Niemayer e Lúcio Costa como arquiteto e paisagista.

A construção da cidade de Brasília provocou um significativo êxodo populacional para o interior do país, onde pessoas originárias de diversas regiões, principalmente do norte e do nordeste passaram a lá residir com suas famílias em busca de melhores perspectivas de futuro. Isso provocou uma convergência de culturas regionais decorrentes dos hábitos familiares, de convívio social e modo de vida peculiar que essas pessoas trouxeram de suas regiões de origem.

\section{FEDERALISMO E CULTURA NA CONSTITUIÇÃO DE 1967}

Com golpe militar ocorrido em 1964, a considerável abertura democrática adquirida pela Constituição de 1946 foi perdida. 0 art. 153 § $8^{\circ}$ dispunha que:

É livre a manifestação de pensamento, de convicção política ou filosófica, bem como a prestação de informação independentemente de censura, salvo quanto a

25 BRASIL. Constituição Federal. Brasília: Senado Federal, 1946. http://www.planalto.gov.br/ccivil_03/Constituica01946. Acesso em: 23 dez. 2016. 26 BRASIL. Constituição Federal. Brasília: Senado Federal, 1946. http:// www.planalto.gov.br/ccivil_03/Constituica01946. Acesso em: 23 dez. 2016. 27 BRASIL. Constituição Federal. Brasília: Senado Federal, 1946. http://www.planalto.gov.br/ccivil_03/Constituica01946. Acesso em: 23 dez. 2016.

Disponível em:

Disponível em:

Disponível em: 
diversões e espetáculos públicos, respondendo cada um, nos termos da lei, pelos abusos que cometer. É assegurado o direito de resposta. A publicação de livros, jornais e periódicos não depende de licença da autoridade. Não serão, porém, tolerados a propaganda de guerra, de subversão da ordem ou de preconceitos de religião, de raça ou de classe, e as publicações e exteriorizações contrárias à moral e aos bons costumes. ${ }^{28}$

Observa-se que, este dispositivo referente ao capítulo referente aos Direitos e Garantias Fundamentais, cerceia a livre manifestação do pensamento nas diversões nos espetáculos públicos, ou que podemos traduzir como ma limitação á expressão cultural no campo da música, do teatro, assim como as publicações que também eram passíveis de punição caso fossem contrárias a moral e aos bons costumes. Acresça-se ainda, que no Título IV, o legislador repete o que mencionara nas constituições pretéritas, ao tratar o campo cultura juntamente com os tópicos relativos á família e a educação.

$\mathrm{E}$, do que pode se extrair acerca da cultura ou assuntos a ela relacionados são os artigos 179 e 180. 0 art. 179 estabelecia que: “Art 179. As ciências, as letras e as artes são livres, ressalvado o disposto no $\S 8^{\circ}$ do artigo $153^{\prime 29}$. Assim, como vimos anteriormente, era explícita a restrição do legislador constituinte da manifestação no âmbito cultural.

Em decorrência do regime militar fruto do golpe de 1964, qualquer espécie de manifestação que fosse de encontro com os ideais daquela realidade conjuntural culminaria na prisão, tortura ou qualquer outro tipo de punição em desfavor daqueles que direta ou indiretamente se pronunciasse com ideias contrárias ás do governo.

Entretanto, se por um lado houve certa castração na liberdade artística e cultural ou mesmo de pensamento, que levou políticos e artistas a serem exilados em outros países, foi uma época na qual uma considerável parcela desses artistas, a exemplo de Chico Buarque, Geraldo Vandré e Caetano Veloso, elaborassem as mais belas canções de modo a divulgá-las através de mensagem subliminar ás pessoas em decorrência da censura da época. 0 outro dispositivo que merece destaque é o artigo 180, o qual dispõe da seguinte forma:

Art. 180. O amparo á cultura é dever do Estado.

28 BRASIL. Constituição Federal. Brasília: Senado Federal, 1967. Disponível em: https://www.planalto.gov.br/ccivil_03/constituicao/constituicao.htm67. Acesso em: 23 dez. 2016. 29 BRASIL. Constituição Federal. Brasília: Senado Federal, 1967. Disponível https://www.planalto.gov.br/ccivil_03/constituicao/constituicao.htm67. Acesso em: 23 dez. 2016. 
Parágrafo único. Ficam sob a proteção especial do Poder Público os documentos, as obras e os locais de valor histórico ou artístico, os monumentos e as paisagens naturais notáveis, bem como as jazidas arqueológicas. ${ }^{30}$

Observa-se que o legislador restringiu-se a dizer que a cultura era dever do Estado, destacando alguns itens a ela relativos como protegidas pelo Poder Público. Não houve uma explicita descentralização entre as esferas federal e estadual, como seria de se esperar de um regime federativo.

Vê-se que a proteção contida no parágrafo único ficou a cargo do “Poder Público', o que poderia ser interpretado como poder federal, ou seja, um papel da União. Cumpre salientar ainda, que o legislador nem mesmo cogitou atribuir uma responsabilidade explícita dos municípios mesmo que não houvesse autonomia federativa, á época, como ocorrera no art. 134 da Constituição de 1937.

A Emenda Constitucional No 1 de 1969 praticamente alterou todo o texto constitucional, sendo considerada por alguns como mais uma carta magna no nosso País. Contudo, considerada ou não uma constituição, as mudanças ocorridas com a referida emenda não alterou os dispositivos relativos á cultura no Brasil.

O fim do regime militar ocorreu de modo gradativo, com a anistia concedida a muitos dos exilados que puderam retornar ao país na década de 1970. Porém, somente na década seguinte é que vislumbraríamos uma perspectiva de abertura democrática. No que se refere ao regime federativo, este mal existia em sua forma, quanto mais em sua substância.

Alguns anos anteriores ao advento da Constituição de 1988, Marcos Vinícios Vilaça, já prenunciava uma maior atenção governamental na seara da cultura, salientando a cooperação das esferas do poder público para o implemento de ações nesta esfera tão esquecida, mas tão fundamentais ao desenvolvimento do país. Nesse sentido, Vilaça assegurou:

Vale dizer, vem aí um novo plano de desenvolvimento nacional e seu plano setorial de educação, cultura e desportos. Não podemos, de modo algum, fugir à responsabilidade de estarmos presentes na formulação destes planos, sob pena de sermos julgados pela história como omissos. ${ }^{31}$

30 BRASIL. Constituição Federal. Brasília: Senado Federal, 1967. Disponível em: https://www.planalto.gov.br/ccivil_03/constituicao/constituicao.htm67. Acesso em: 23 dez. 2016.

31 VILAÇA, Marcos Vinícios. Por uma política nacional de cultura. Brasília: Fundação Nacional pró Memória, 1984, p. 35. 
E este deverá ser um esforço a ser desenvolvido em conjunto, pelas três esferas da administração pública, em parceria com a iniciativa privada e com as entidades da sociedade civil pertinentes à área.

\section{FEDERALISMO E CULTURA NA CONSTITUIÇÃO DE 1988.}

Diante do maior período democrático de nossa história, encontramo-nos diante de uma Constituição que, comparada a todas, deu maior relevo á questão da cultura. Inicialmente merece comentário o artigo 215 no qual o estado assegura a todos o pleno exercício dos direitos culturais. O referido dispositivo garante o apoio, incentivo, valorização e difusão das manifestações culturais.

Dada a necessidade de regulamentar as ações a serem implementadas pelo poder público visando o desenvolvimento cultural no país, foi criada a Lei. 13.343 de 02.12.2010, instituindo o plano nacional de cultura, PNC, criando também o Sistema Nacional de Informações e indicadores Culturais - SNIIC.

Já o artigo 216 regulamenta os bens que constituem o patrimônio cultural brasileiro neles incluídos os de natureza material e imaterial, cuja promoção fica a cargo do Poder Público juntamente com a colaboração da comunidade.

Houve ainda a preocupação do legislador em tratar de promover leis para o incentivo á cultura no país. Dentre as existentes, destacamos a Lei. 8.313/91, que ficou conhecida como “Lei Rouanet", que dispõe sobre uma série de benefícios na área fiscal que são concedidos no caso de realização de operações de caráter cultural ou artístico. O legislador ainda facultou aos Estados e ao distrito Federal um percentual de sua receita tributária líquida (até meio por cento) para vincular a fundo estadual de fomento á cultura.

Em decorrência da Emenda Constitucional 71, de 29.11.2012 foi instituído o sistema Nacional de Cultura, acrescentando assim o artigo 216-A á Constituição. Esse dispositivo tem seu caput com a seguinte redação:

Art. 216-A. O Sistema Nacional de Cultura, organizado em regime de colaboração, de forma descentralizada e participativa, institui um processo de gestão e promoção conjunta de políticas públicas de cultura, democráticas e permanentes, pactuadas entre os entes da Federação e a sociedade, tendo por objetivo promover o desenvolvimento humano, social e econômico com pleno exercício dos direitos culturais. ${ }^{32}$

32 BRASIL. Constituição Federal. Brasília: Senado Federal, 1988. Disponível em: 
Dentre os princípios que o regem, é importante ressaltar os incisos IV que prevê a "cooperação entre os entes federados, os agentes públicos e privados atuantes na área cultura." e o VIII que ressalta a "autonomia dos entes federados e das instituições da sociedade civil".

Mesmo cientes da cooperação e da autonomia entre os entes e das instituições, elencados acima, muito ainda há de ser feito para que essa cooperação seja efetivada na prática, uma vez que ainda carecemos de uma maior delimitação e melhor ajustamento entre a União, os estados e os municípios a fim de que essa cooperação se configure de forma harmônica, evitando assim que dois entes realizem o mesmo trabalho ou serviço ou mesmo o façam de forma destoante. Assim, a gestão em si para efetivação do Sistema Nacional de Cultura ainda carece de uma sistematização. Na visão de Souza:

A plena consolidação e efetivação dos direitos culturais em todas suas vertentes não dependem unicamente do poder executivo, mas são de responsabilidade de todas as instâncias estatais, com as quais a sociedade civil está obrigada a colaborar. Porém é indiscutível o proeminente papel do poder executivo na elaboração do conteúdo e definição dos contornos infraconstitucionais que estes direitos irão assumir no ordenamento nacional. Daí a importância de políticas públicas consistentes, viáveis e sustentáveis, com destaque para a elaboração e execução do orçamento. ${ }^{33}$

Analisando os incisos acima destacados, percebemos que os mesmos se adéquam a já existente previsão constitucional, á época de sua promulgação que já previa ações cooperadas entre os entes da nossa federação na esfera cultural como demonstraremos a seguir. Entretanto, cabe destacar que, mesmo antes da referida emenda constitucional, estudiosos da área já apontavam a necessidade de um sistema de políticas culturais, como apontara CUNHA FILHO (ao dizer:

Logo, um sistema de políticas culturais é duplamente indispensável em um país de federalismo cooperativista, seja porque garante a diversidade intrínseca a uma das facetas de qualquer federação, seja pela necessidade de dar respostas concretas aos deveres públicos para com o setor. Porém os sistemas costumam ser reflexo da concepção que se adota para o todo da estrutura federalista. ${ }^{34}$

https://www.planalto.gov.br/ccivil_03/constituicao/constituicao.htm. Acesso em: 23 dez. 2016.

${ }^{33}$ SOUZA, Alan Rocha. Direitos Culturais no Brasil. Rio de Janeiro: Azougue, 2012, p.90.

${ }^{34}$ CUNHA FILHO, Francisco Humberto. Federalismo brasileiro: significados para cultura. In BARBALHO, Alexandre; BARROS, José Márcio; CALABRE, Lia. Federalismo e políticas culturais no Brasil. Salvador, Edufba, 2013, p.35. 
É do conhecimento de todos que a Constituição de 1988 trouxe mudanças em vários aspectos. No tocante ao sistema federativo como forma de organização estatal, destacamos a recepção do município como ente autônomo. Desse modo, o Brasil passou a ter um federalismo próprio, considerado tridimensional, já que União, estados membros e municípios gozam de autonomia e atribuições próprias.

É forçoso reconhecer que o federalismo brasileiro está bem distante do modelo ideal almejado por tantos juristas e pesquisadores da atualidade. Contudo, a estrutura federativa brasileira é a melhor que tivemos até hoje, muito embora haja ainda uma reconhecida desproporção de atribuições, que se apresentam como resquícios de um passado histórico com forte centralização além de uma oscilação quase que condizente com a oscilação de nosso períodos democráticos.

Outro aspecto importante que merece ser destacado aqui se refere ás matérias que podem ser objeto de competência comum entre os três entes da nossa federação, caracterizando assim o federalismo cooperativo. Dentre elas, observaremos que alguns dos incisos insculpidos no artigo 23 possuem relação com a cultura e a proteção desses direitos.

\footnotetext{
Art. 23 É competência comum da União, dos Estados, do Distrito Federal e dos Municípios:

III - proteger os documentos, as obras e outros bens de valor histórico, artístico e cultural, os monumentos, as paisagens naturais notáveis e os sítios arqueológicos; IV - impedir a evasão, a destruição e a descaracterização de obras de arte e de outros bens de valor histórico, artístico ou cultural;

V - proporcionar os meios de acesso á cultura, á educação e á ciência.

parágrafo único. Leis complementares fixarão normas para a cooperação entre a União e os Estados, o Distrito Federal e os Municípios, tendo em vista o equilíbrio do desenvolvimento e do bem-estar em âmbito nacional. ${ }^{35}$
}

Como se pode observar, a efetivação de direitos culturais nos moldes previstos na Constituição Federal vigente é de competência dos três entes de nossa federação que devem, sob a forma cooperada, buscar as diretrizes delineadoras das atribuições de casa ente no que diz respeito a melhor forma de trabalhar conjuntamente.

35 BRASIL. Constituição Federal. Brasília: Senado Federal, 1988. Disponível em: https://www.planalto.gov.br/ccivil_03/constituicao/constituicao.htm. Acesso em: 23 dez. 2016 


\section{CONCLUSÃO}

O Estado brasileiro, no decorrer de sua história constitucional trouxe consigo em praticamente todas as constituições, a manifesta intenção de proteção do patrimônio histórico cultural o que, hodiernamente se configura como proteção aos direitos culturais.

No entanto, é forçoso reconhecer que esse reconhecimento, sempre existente, mas destacado de maneira tímida no ordenamento jurídico constitucional foi sempre crescente com leves oscilações no decorrer dos tempos, mas que hoje conta com dispositivos bastantes significativos para o exercício de tais direitos, embora não exaustivos e ainda carecedores de legislação infraconstitucional que permita a sua regulamentação.

Paralelamente, analisamos a trajetória federativa brasileira que, ao contrário dos direitos culturais, é marcada de um histórico que oscila com momentos de maior ou menor desconcentração político-administrativa do poder entre os entes formadores de nossa federação.

Sob a perspectiva de que os pilares de um sistema federativo estão baseados na unidade e diversidade, e que os direitos culturais são essenciais ao desenvolvimento e bem estar de uma sociedade democrática, e que a cultura no Brasil é caracterizada também pela diversidade, nos permite concluir que federalismo e a cultura, devem progredir juntos.

Apesar do passado constitucional brasileiro não conferir tanto relevo á questão cultural assim como o federalismo sempre foi alvo de críticas face ao elevado grau de concentração de poder em um determinado ente em detrimento dos demais, a partir da Constituição de 1988 o desenvolvimento dos direitos culturais nela insculpidos, necessitarão do nosso sistema federativo, em especial, do federalismo cooperativo para que os mesmos sejam efetivados.

Vale dizer, que a partir dos direitos culturais poderemos efetivar as práticas de cooperação entre os entes ou, de outro modo, que a existência do federalismo cooperativo fomentará a efetivação dos direitos culturais em nosso país, numa verdadeira relação simbiótica onde, agora, um não poderá viver dissociado do outro para existir de modo pleno e efetivo.

Entretanto, apesar da existência da norma constitucional destacada no Art. 23, este dispositivo ainda carece de regulamentação para que se efetive a cooperação prevista. 0 Parágrafo Único no citado dispositivo prevê a necessidade de leis complementares para regulamentar tais matérias. No entanto, passadas quase três décadas se sua promulgação, à exceção da lei complementar 140 de 2011, (que cuja matéria refere-se à questão ambiental), nenhuma outra lei surgiu para efetivar a prática cooperativa, que se torna incipiente e 
carecedora de regulamentação enquanto tais normas não forem elaboradas de modo a conferir a cooperação desejada pelo legislador constituinte.

\section{REFERÊNCIAS}

BARROS, Alexandre Rands. Desigualdades Regionais e Desenvolvimento Econômico. In Pedro Ferreira... et al. Desenvolvimento Econômico: uma perspectiva brasileira. Rio de Janeiro: Elsevier, 2013.

BASTOS, Aureliano Cândido de Tavares. A Província - Estudo sobre a descentralização no Brasil. Brasília: Edição Fac-Similar. Senado Federal, 1996.

BERCOVICI, Gilberto. Dilemas do Estado Federal Brasileiro. Porto Alegre: Livraria do Advogado, 2004.

BONAVIDES, Paulo. A Constituição Aberta. Temas políticos e constitucionais da atualidade, com ênfase no Federalismo de Regiões. $2^{\text {a }}$ Ed. São Paulo: Malheiros, 1996.

BRASIL. Constituição Federal. Brasília: Senado Federal, 1891. Disponível em: https://www.planalto.gov.br/ccivil_03/constituicao/constituicao24.htm. Acesso em: 23 dez. 2016.

BRASIL. Constituição Federal. Brasília: Senado Federal, 1934. Disponível em: https://www.planalto.gov.br/ccivil_03/constituicao/constituicao34.htm. Acesso em: 23 dez. 2016.

BRASIL. Constituição Federal. Brasília: Senado Federal, 1937. Disponível em: https://www.planalto.gov.br/ccivil_03/constituicao/constituicao37.htm. Acesso em: 23 dez. 2016.

BRASIL. Constituição Federal. Brasília: Senado Federal, 1946. Disponível em: http://www.planalto.gov.br/ccivil_03/Constituicao1946. Acesso em: 23 dez. 2016.

BRASIL. Constituição Federal. Brasília: Senado Federal, 1967. Disponível em: https://www.planalto.gov.br/ccivil_03/constituicao/constituicao.htm67. Acesso em: 23 dez. 2016.

BRASIL. Constituição Federal. Diário Oficial da União. Brasília: Senado Federal, 1988. Disponível em: https://www.planalto.gov.br/ccivil_03/constituicao/constituicao.htm. Acesso em: 23 dez. 2016.

CARDOSO, Fernando Henrique. Pensadores que inventaram o Brasil. São Paulo: Companhia das Letras, 2013.

CUNHA FILHO, Francisco Humberto. Federalismo brasileiro; significados para cultura. In BARBALHO, Alexandre; BARROS, José Márcio; CALABRE, Lia. Federalismo e políticas culturais no Brasil. Salvador, Edufba,2013. 
FURTADO, Celso. Essencial Celso Furtado. São Paulo, Penguin Classics Companhia das Letras; 2013.

LIMA, Oliveira. Formação da Nacionalidade Brasileira. 3ed. Rio de Janeiro: Publifolha, 2000.

MADISON, James; HAMILTON, Alexander; JAY, John. Os Artigos Federalistas. Apresentação:

Isaac Kramnick; tradução de Maria Luiza X. de A. Borges. Rio de Janeiro: Nova Fronteira, 1993.

MONTESQUIEU ( Charles Louis de Secondat). Do Espírito das Leis. Rio de Janeiro: Nova Cultural, 1997.

RIBEIRO, Darcy. O Povo Brasileiro: A formação e o sentido de Brasil. 2a ed. São Paulo:

Companhia das Letras, 1995.

SCHWARCZ, Lília Moritz. As barbas do imperador: D. Pedro II, um monarca dos trópicos. 2ed. São Paulo; Companhia das Letras, 2003.

SOUZA, Alan Rocha. Direitos Culturais no Brasil. Rio de Janeiro: Azougue, 2012.

VILAÇA, Marcos Vinícios. Por uma política nacional de cultura. Brasília: Fundação Nacional pró Memória, 1984.

Recebido em: 20/01/2017 / Revisões requeridas em: 19/04/2017 / Aprovado em: 24/05/2017

SOARES FILHO, Sidney; PONTE, Marcelo Dias. CULTURA E FEDERALISMO NA TRAJETÓRIA CONSTITUCIONAL BRASILEIRA. Revista Eletrônica do Curso de Direito da UFSM, Santa Maria, RS, v. 12, n. 2, p. 517-544, ago. 2017. ISSN 1981-3694. Disponível em: <https://periodicos.ufsm.br/revistadireito/article/view/25661>. Acesso em: dia mês. ano.

doi:http://dx.doi.org/10.5902/1981369425661. 